\title{
Practical Artificial Neural Network Tool for Predicting the Competitive Adsorption of Dyes on Gemini Polymeric Nanoarchitecture
}

\author{
A. El Bey, ${ }^{a}$ M. Laidi, ${ }^{a}{ }^{*}$ A. Yettou, ${ }^{a}$ S. Hanini, ${ }^{a}$ \\ A. Ibrir, M. Hentabli, and H. Ouldkhaoua ${ }^{a}$ \\ a Laboratory of Biomaterials and Transport Phenomena (LBMPT), University of Médéa, Algeria \\ b Laboratory Quality Control, Physico-Chemical Department, \\ Antibiotical Saidal of Médéa, Algeria
}

This work is licensed under Creative Commons Attribution 4.0 International License

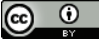

\begin{abstract}
The objective of this study was to model the removal efficiency of ternary adsorption system using feed-forward back propagation artificial neural network (FFBP-ANN). The ANN model was trained with Levenberg-Marquardt back propagation algorithm and the best model was found with the architecture of $\{9-11-4-3\}$ neurons for the input layer, first and second hidden layers, and the output layer, respectively, based on two metrics, namely, mean squared error (MSE) $=(0.2717-0.5445)$ and determination coefficient $\left(R^{2}\right)=(0.9997-0.9999)$. Results confirmed the robustness and the efficiency of the developed ANN model to model the adsorption process.
\end{abstract}

Keywords

Competitive adsorption, artificial neural networks, modelling, dyes

\section{Introduction}

Adsorption is one of the most effective unit operations employed for the removal of dye pollutants from wastewater ${ }^{1}$ with respect to removal capacity with high quality adsorbate, low cost, and energy feeding. ${ }^{2}$ Dyes can exist in the wastewater as acid, cationic, direct, dispersed, and reactive, and can be adsorbed from aqueous effluents using several adsorbents. ${ }^{3}$ The increasing number of parameters required for competitive adsorption process description leads to complicating the modelling and optimisation process of the real phenomenon. ${ }^{4,5}$ Several isotherms and non-linear models have been proposed in the literature to fit the multi-component adsorption systems, ${ }^{3}$ namely, modified-Langmuir isotherm, extended-Langmuir isotherm, extended-Freundlich isotherm, and ideal adsorbed solution theory (IAST) based model, etc. ${ }^{6}$ Recently, artificial intelligence approaches have been proving their capacity in modelling the complex and non-linear behaviour of multi-component adsorption systems such as artificial neural networks (ANN), ${ }^{7}$ support vector machines (SVMs) ${ }^{8,9}$ used with default optimisation algorithms or with recently published methods like swam or dragonfly optimisation techniques. Thus, the novelty of the present study is the development of an accurate ANN model to predict the removal efficiency of three dyes, namely, \{blue acid 92, direct green 6, direct red 31\} on Gemini polymeric nanoarchitecture.

\section{Methodology}

In this work, the input parameters for the ANN model were selected based on their availability in a selected scientif-

*Corresponding author: Dr Maamar Laidi

Email: maamarw@yahoo.fr ic published paper, as well as on their effect on the outputs. The data set was directly extracted from the experimental curves using digitiser software from paper. ${ }^{10}$ The selected parameters in this paper were $\lambda_{\max }$ of each dye \{blue acid 92, direct green 6 , direct red 31$\}$, molecular weight of the salts used $\left\{\mathrm{NaHCO}_{3}, \mathrm{Na}_{2} \mathrm{CO}_{3}, \mathrm{Na}_{2} \mathrm{SO}_{4}\right\}$, initial concentration of each dye $\left\{300 \mathrm{mg} \mathrm{I}^{-1}, 400 \mathrm{mg} \mathrm{I}^{-1}\right.$, $\left.500 \mathrm{mgl}^{-1}, 600 \mathrm{mgl}^{-1}\right\}$, weight of the adsorbent $\left\{\mathrm{m}_{\mathrm{ad}}\right.$ : $0.025 \mathrm{~g}, 0.05 \mathrm{~g}, 0.075 \mathrm{~g}, 0.1 \mathrm{~g}, 0.125 \mathrm{~g}\}$, adsorption time $\{t: 2.06-60 \mathrm{~min}\}$, and the maximum dye adsorption capacity $\left\{q_{\mathrm{e} 1}, q_{\mathrm{e} 2}, q_{\mathrm{e} 3}\right\}$ considered as outputs. The data set can be arranged in the matrix of $\{12,414\}$ data points and then randomly divided into three subsets to train/validate and test the model. The data set is normalised between $[-\beta \gamma,(1-\beta) \gamma]$ which helps to achieve a higher training accuracy and leads to stable convergence of network weights and biases by having all inputs with the same range of values and using premnmx/postmnmx function already programmed in the MATLAB software, and expressed by the following equation:

$$
x_{\text {in }}=\gamma \frac{x_{i}-x_{\text {min }}}{x_{\text {max }}-x_{\text {min }}}-\beta \gamma
$$

In this work, $\beta=0.5$ and $\gamma=2$ were selected, and the scaled values of each input were computed. $x_{i}$ and $x_{i n}$ are its original and normalised value, $x_{\max }$ and $x_{\min }$ are the maximum and the minimum of $x$. Outputs anti-normalisation can be performed using the following expression:

$$
x_{i}=\left(\frac{1}{\gamma}\right) \cdot\left(x_{\text {in }}+\beta \gamma\right) \cdot\left(x_{\max }-x_{\min }\right)+x_{\text {min }}
$$

A supervised training strategy with Levenberg-Marquardt algorithm was adopted as default in this study. Different significant aspects of the building of ANN models are the network structure, i.e., transfer function, the number of 


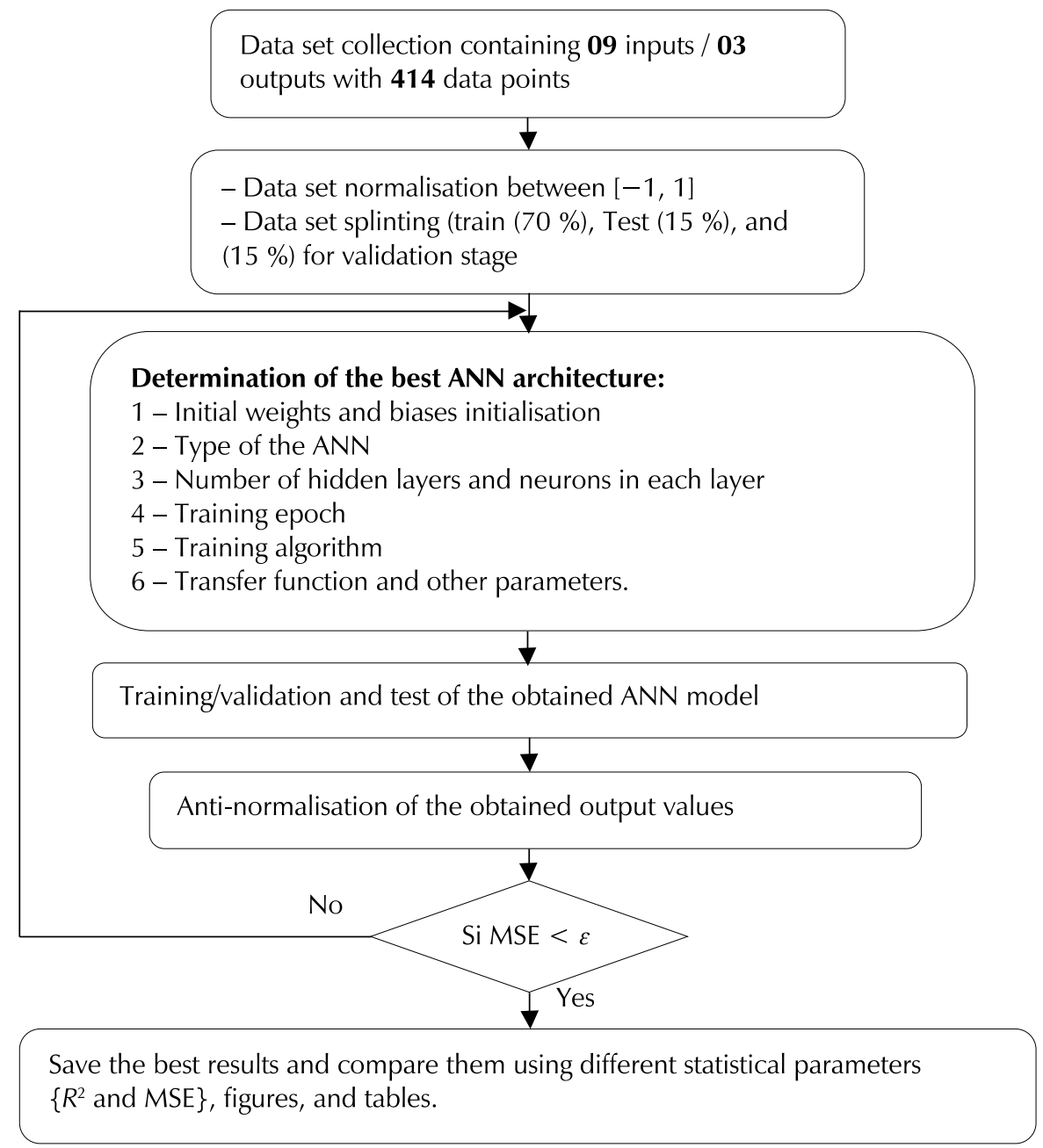

Fig. 1 - Flow chart of ANN development methodology ${ }^{11}$

hidden layers, and the number of neurons in each layer. The number of inputs and outputs is usually in direct relation to the examined problem, and is defined as the number of controlling parameters of the process (inputs) and the number of parameters directly affecting them (outputs). However, there is no rule for the exact determination of the number of hidden layers and the number of neurons in each layer. Usually, the optimal hidden layers and neurons in the ANN model can be conducted solely by trial-and-error method, and based on the calculation of some statistical parameters, i.e., errors and regression coef- ficient. To avoid overfitting of the ANN model, each architecture was changed 20 times, and all parameters were selected randomly like initial weights and biases. A detailed flow chat of the ANN methodology is given in Fig. 1, and implemented in convivial and flexible MATLAB program to test all parameters and save the optimal weights and biases and other optimised parameters for further use for ANN prediction.

Such modelling technique works like a "black box" where the basic process of this method is shown in Fig. 2.

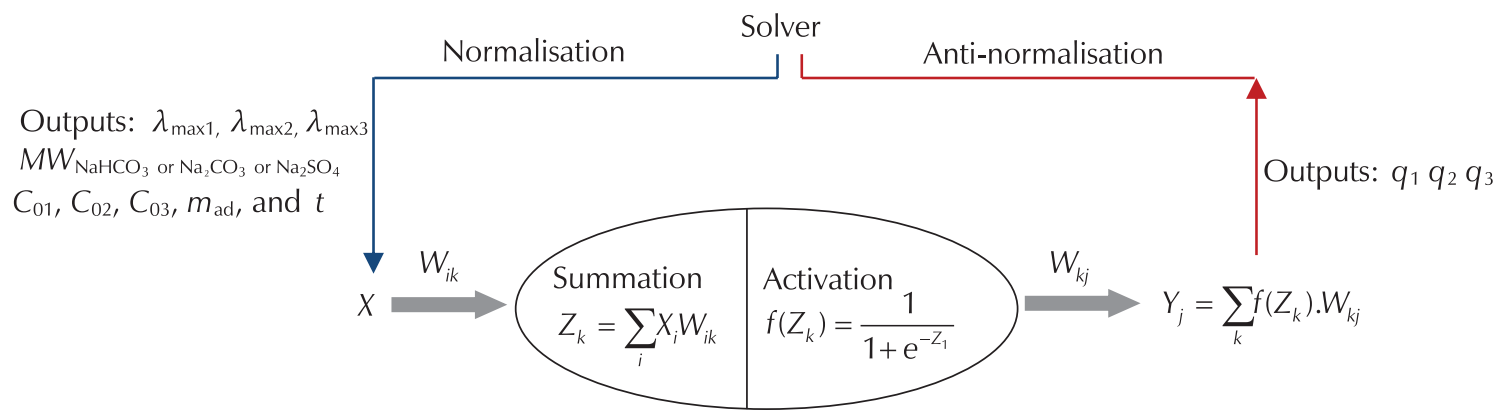

Fig. 2 - Involved process in the BP-ANN library ${ }^{12,13}$ 


\section{Results and discussion}

The comparison between experimental and calculated values was conducted using mean squared error (MSE), which was the main criterion to evaluate the accuracy of ANN. Generally, the prediction ability of ANN model is related directly to the small mean squared error (MSE) of training and validation stage. This error is defined as follows as:11,14

$$
\mathrm{MSE}=\frac{1}{n} \sum_{i=1}^{n}\left(y_{i}^{\mathrm{exp}}-y_{i}^{\mathrm{cal}}\right)^{2}
$$

where $n$ is the total number of data, $y_{i}^{\exp }, y_{i}^{\text {cal }}$, and $\overline{y^{\exp }}$ are the target and network output values, and the mean of the experimental values, respectively. The determination coefficient $R^{2}$ is also used to confirm the performance of the best developed models, and can be expressed by the following equation: ${ }^{15}$

$$
R^{2}=1-\frac{\sum_{i=1}^{n}\left(y_{i}^{\exp }-y_{i}^{\text {cal }}\right)^{2}}{\sum_{i=1}^{n}\left(y_{i}^{\exp }-\overline{y^{\exp }}\right)^{2}}
$$

The coefficient of determination is a statistical measurement that assesses how strong the linear relationship is between the two variables. In this work, a feed-forward back propagation - multi-layer artificial neural network
(FFBP-ANN) coded in MATLAB as newff was used and trained with Levenberg-Marquardt algorithm implemented in MATLAB software, and expressed as trainlm. ${ }^{16}$ The test of three transfer functions was performed using \{hyperbolic tangent sigmoid (tansig), log-sigmoid (logsig), and linear (purelin)\}. After 3000 iterations, results showed that an ANN model with one hidden layer, including in it different neurons, was unable to fit the behaviour of multi-component adsorption system. Thus, an ANN with two hidden layers was used, where the number of neurons in every layer was changed from 1 to 20 . Fig. 3 shows the variation of MSE in divided ranges against the number of neurons in every hidden layer. It was found that an ANN model with two hidden layers and with the structure of \{9-11-4$3\}$ neurons in input layer, first and second hidden layers, and the output layer, respectively, can precisely predict the maximum dye adsorption capacity on Gemini polymeric nanoarchitecture (GPN). Table 1 summarises the architecture of the final ANN model.

Fig. 3 shows the structure of the obtained ANN, including the number of hidden layers, number of neurons in each layer, and transfer function used in each layer.

Fig. 4 shows a 3D plot of the performance of the developed network with two hidden layers in terms of MSE. The best structure was found to be $\{9-11-4-3\}$ in the input layer, first and second hidden layers, and the output layer, respectively. The best ANN model was found with very low

\begin{tabular}{|c|c|c|c|c|c|c|}
\hline \multirow{2}{*}{ Network type } & \multirow{2}{*}{ Training algorithm } & Input layer & \multicolumn{3}{|c|}{ Hidden layer } & \multirow{2}{*}{ Output layer } \\
\hline & & \multirow{2}{*}{$\begin{array}{l}\text { No. of } \\
\text { neurons }\end{array}$} & Parameters & $1^{\text {st }}$ hidden layer & $2^{\text {nd }}$ hidden layer & \\
\hline \multirow{2}{*}{$\begin{array}{l}\text { FFNN-BP } \\
\text { newff }\end{array}$} & \multirow{2}{*}{$\begin{array}{c}\text { Levenberg-Marquardt } \\
\text { trainlm }\end{array}$} & & No. of neurons & 11 & 4 & 3 \\
\hline & & 9 & Transfer function & \multicolumn{2}{|c|}{ tansig } & purelin \\
\hline
\end{tabular}

Table 1 - Architecture of the optimised ANN model

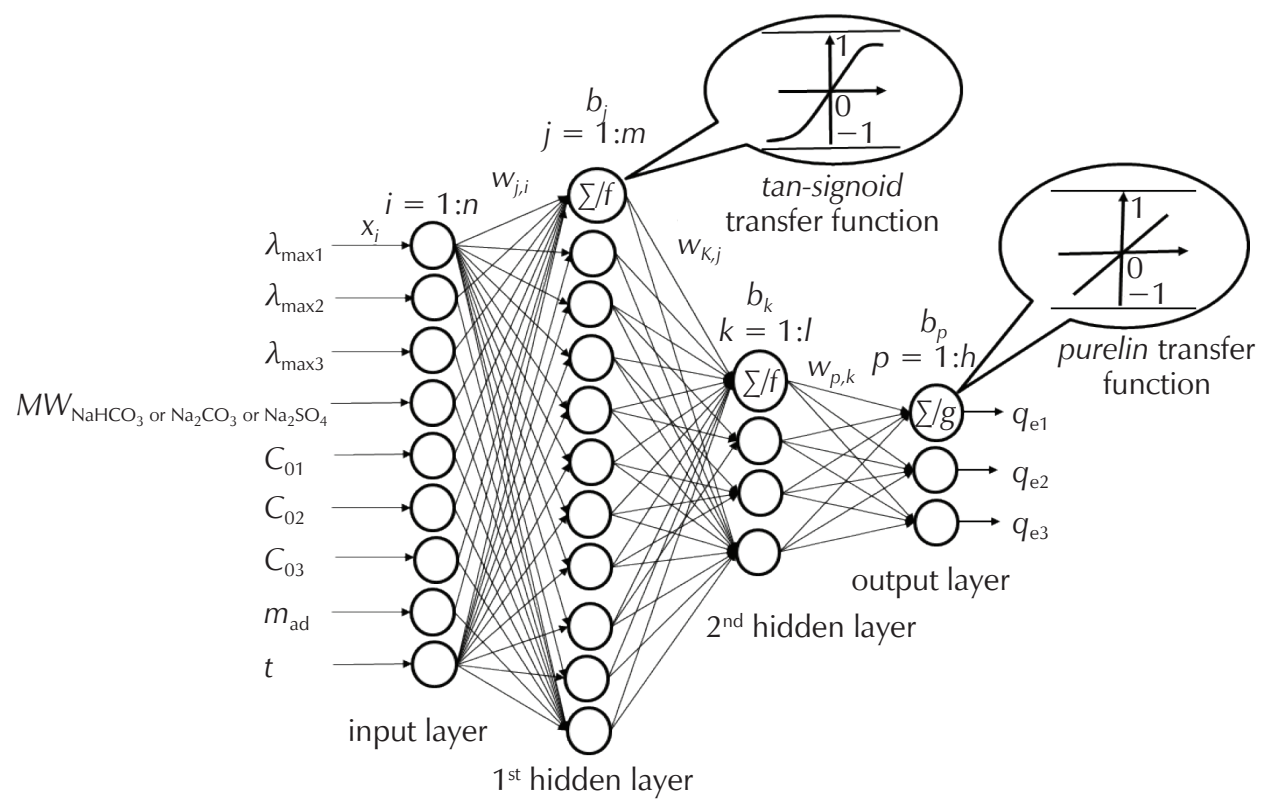

Fig. 3 - ANN detailed structure 


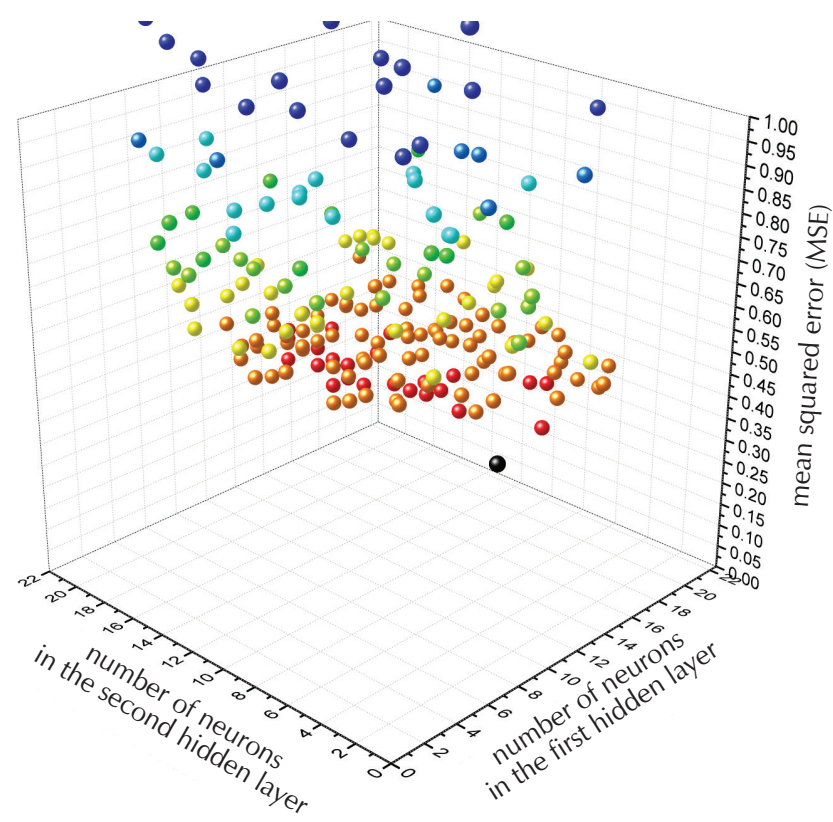

Fig. 4 - Performance of network in terms of MSE with two hidden layers

MSE of $\{0.2717,0.2885,0.5445\}$ for the three outputs. These results confirmed that this model could be used to perform similar tasks in the future.

Another comparison in terms of regression curves was conducted to confirm the accuracy of the developed model in

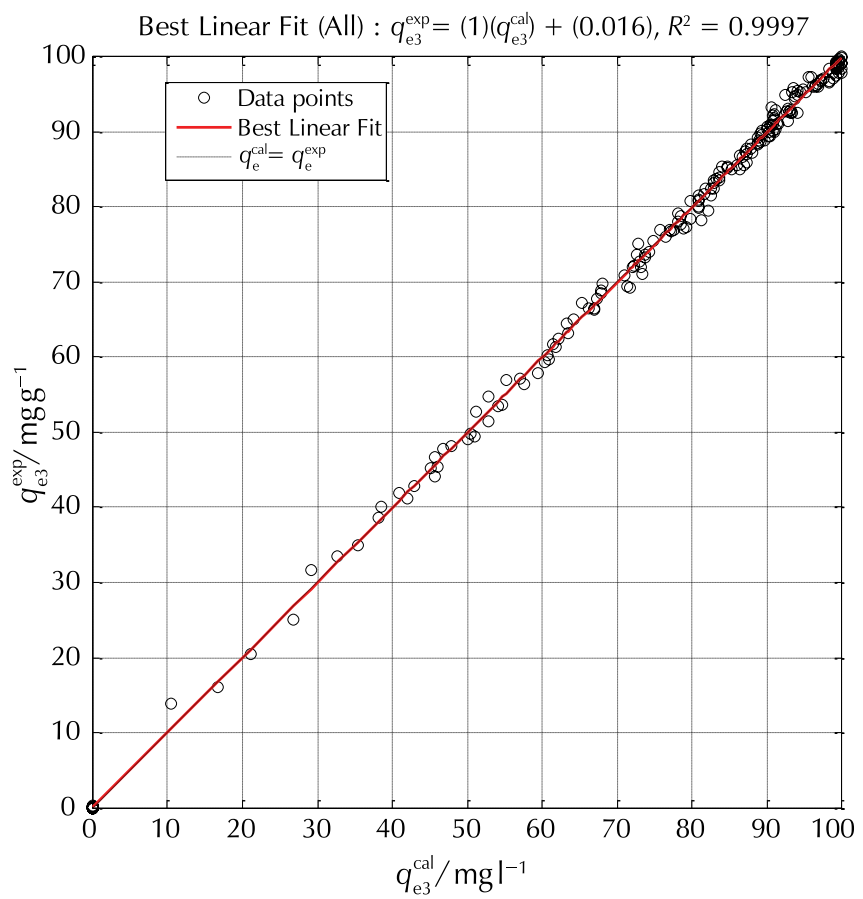

predicting the three maximum dye adsorption capacities for the global data set. The results clearly showed that all the points were located on the first bisector, the predictions matched well the experience and were almost identical with the regression coefficient approaching the ideal [ $\alpha$ (slope), $\beta$ (y-intercept), $R^{2}$ (determination coefficient) $]=$ $[1.0003,0.0097,0.9999]$ for the first adsorbed capacity, [0.9995, 0.0086, 0.9997] for the second, and the same comparison for the third capacity with linear regression vector equal to [0.9991, 0.0163, 0.9997], as may be seen in Fig. 5. This confirmed the robustness of the developed ANN model. The experimentally adsorbed dyes and the ANN predictions matched well with each other, and were
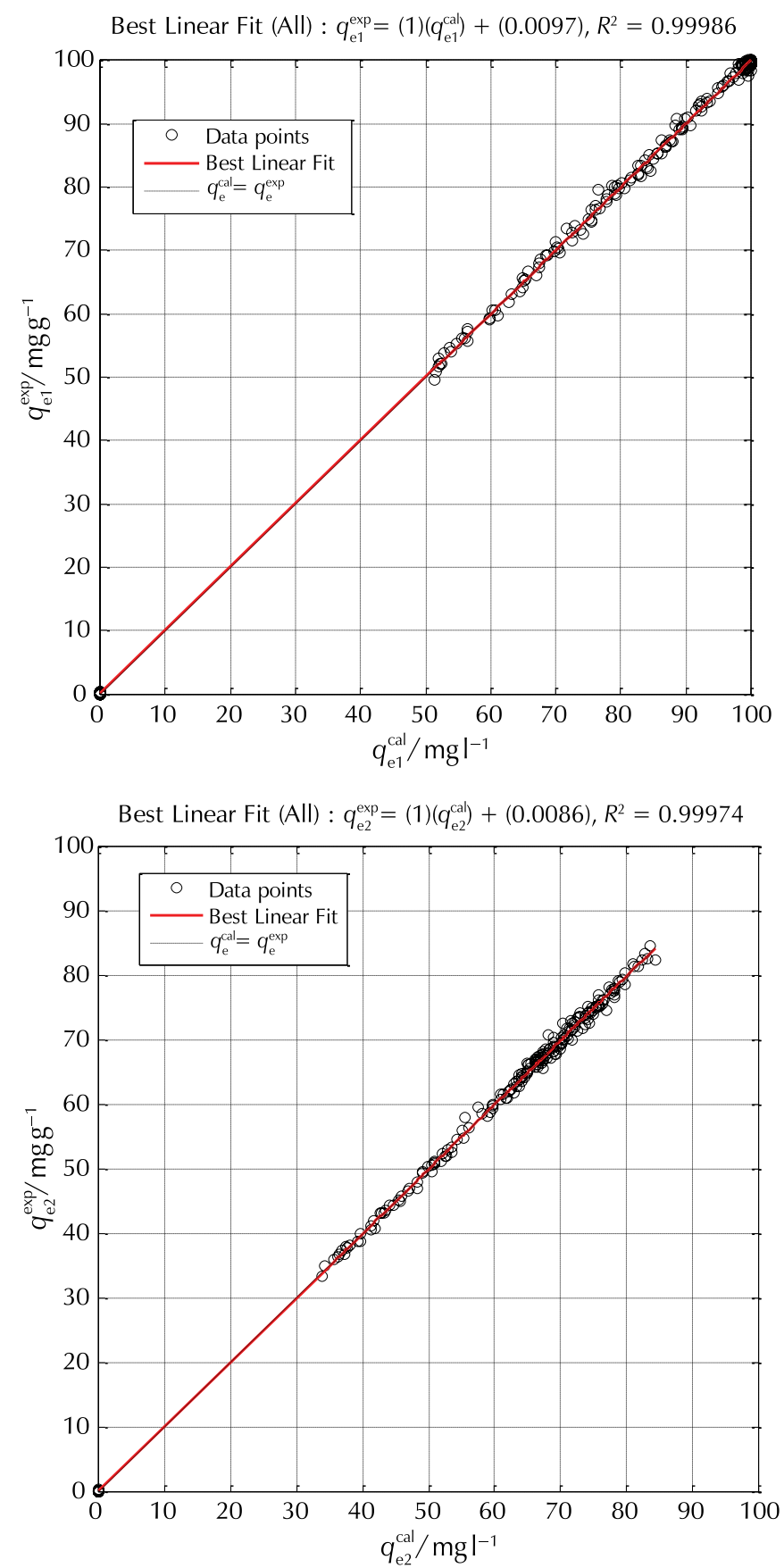

Fig. 5 - Correlation between the experimental and ANN predictions for the three outputs 
almost the same. It is clear that all the values of the determination coefficient are larger than 0.999 and approach unity for each output model.

The present accuracy of the developed ANN models is acceptable for further prediction of the three dyes on the Gemini polymeric nanoarchitecture. The three ANN models can be written with the obtained characteristics as follows:

$$
\begin{aligned}
& q_{\mathrm{e} 1}=g\left[\sum_{k=1}^{l} w_{1, k} \cdot f\left[\sum_{j=1}^{m} w_{k, j} \cdot f\left[\sum_{i=1}^{n} w_{j, i} \cdot x_{i}+b_{j}\right]+b_{k}\right]+b_{1}\right] \\
& q_{\mathrm{e} 2}=g\left[\sum_{k=1}^{l} w_{2, k} \cdot f\left[\sum_{j=1}^{m} w_{k, j} \cdot f\left[\sum_{i=1}^{n} w_{j, i} \cdot x_{i}+b_{j}\right]+b_{k}\right]+b_{2}\right] \\
& q_{\mathrm{e} 3}=g\left[\sum_{k=1}^{1} w_{3, k} \cdot f\left[\sum_{j=1}^{m} w_{k, j} \cdot f\left[\sum_{i=1}^{n} w_{j, i} \cdot x_{i}+b_{j}\right]+b_{k}\right]+b_{3}\right]
\end{aligned}
$$

where $I(1: n), j(1: m), k(1: l)$, and $I(1: p)$ are the number of inputs, hidden, and outputs, respectively. $w$ and $b$ are weights and biases, and $f$ is the hyperbolic tangent sigmoid transfer function. Table 2 summarises some statistical parameters of the three ANN models.

Table 2 - Statistical characteristics of the best ANN models

\begin{tabular}{l|c|c|c|c|c}
\hline & $r$ & $m$ & $b$ & $R^{2}$ & MSE \\
\hline ANN- $q_{\mathrm{e} 1}$ & 0.9999 & 1.0003 & 0.0097 & 0.9999 & 0.2717 \\
\hline ANN- $q_{\mathrm{e} 2}$ & 0.9999 & 0.9995 & 0.0086 & 0.9997 & 0.2885 \\
\hline ANN- $q_{\mathrm{e} 3}$ & 0.9998 & 0.9991 & 0.0163 & 0.9997 & 0.5445 \\
\hline
\end{tabular}

To facilitate the use of the developed ANN models in this study, a user-friendly and robust graphical interface tool was written in MATLAB software using Windows 7 as an operating system.

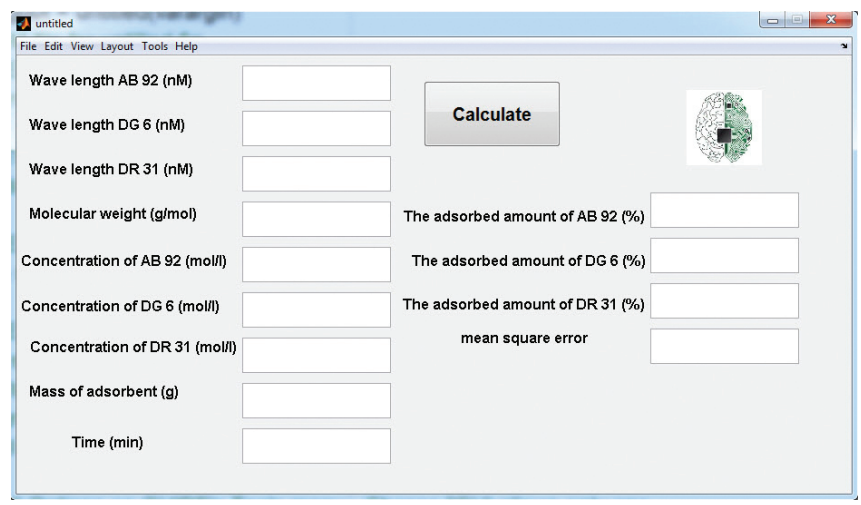

Fig. 6 - Interactive graphical user interface for the developed ANN

Fig. 6 shows the main user interface and allows the user to compute the maximum dye adsorption capacity using well known inputs as numeric values and the obtained weights and biases during the best training stage without learning about any software and without the necessity of knowing deep information about the phenomena. Tables 3-5 show the values of weights and biases obtained during the training stage of the best ANN models that can be used in the graphical user interface.

The performance of the developed model in this study was compared with previously published papers on modelling of dye adsorption by ANN. Results showed that the developed model was capable of predicting the removal efficiency of adsorption of the ternary systems (03 dyes) on

\begin{tabular}{|c|c|c|c|c|c|c|c|c|c|}
\hline \multicolumn{9}{|c|}{ Inputs - first hidden layer connections $W_{j, i\{j=1: 11, i=1: 9\}}$} & \multirow{2}{*}{$\begin{array}{r}b_{j\{j=1: 11\}} \\
1.5257\end{array}$} \\
\hline-0.2687 & 0.2411 & -3.4332 & -2.2448 & 1.4959 & 1.3327 & 0.4634 & 0.9896 & 0.0257 & \\
\hline-1.5694 & 2.3276 & 1.3412 & 0.4434 & -0.9033 & -0.8736 & 1.1966 & -0.1459 & 0.6526 & 0.1720 \\
\hline-0.9318 & -1.2006 & -0.3529 & 0.0966 & -0.9085 & 0.2988 & 1.7608 & -1.6503 & 0.3794 & -4.1602 \\
\hline 0.2585 & 1.5545 & -1.3645 & 0.3191 & 0.5244 & -0.5009 & 1.5006 & -0.1129 & -0.0248 & 0.9853 \\
\hline-3.2264 & -2.0237 & -1.9449 & 3.1959 & 2.0190 & 0.0164 & -0.2311 & -0.5357 & -0.1147 & 2.5986 \\
\hline-0.7980 & -0.3118 & 0.4756 & 0.7857 & 0.0924 & -1.0468 & -0.2292 & -1.6203 & -0.1531 & -0.6863 \\
\hline-0.6695 & 1.3942 & -1.7353 & 0.1815 & -1.8182 & 1.7874 & -0.5414 & -1.9646 & -0.7743 & -1.8070 \\
\hline-5.1156 & -1.0224 & 0.5874 & -0.0317 & -1.6833 & 1.0129 & -0.6226 & 6.0983 & -0.7300 & -2.0662 \\
\hline-2.6532 & 1.5421 & 0.3591 & -2.4902 & -0.3507 & -2.0474 & -2.1333 & 2.0090 & 0.4070 & -2.5515 \\
\hline-2.9416 & -1.0216 & 2.9638 & -1.7829 & -0.0549 & -1.0235 & -1.5027 & -4.9564 & 0.2662 & -4.0447 \\
\hline-0.1567 & -0.9868 & 1.2968 & -1.1524 & 0.3389 & -0.7161 & 1.1100 & -2.3078 & -0.0247 & -1.8012 \\
\hline
\end{tabular}
GPN with high performance (Table 6).

Table 3 - Weights and biases between the input and the first hidden layer 
Table 4 - Weights and biases between the first and the second hidden layer

\begin{tabular}{r|r|r|r|r|r|r|r|r|r|r|r|r|r}
\hline \multicolumn{10}{c}{ First hidden layer - second hidden layer connections $W_{k, j}\{k=1: 4, j=1: 11\}$} & $b_{k\{k=1: 4\}}$ \\
\hline-0.5007 & 1.2423 & 1.3386 & 0.1034 & 4.3695 & -2.7740 & 2.6452 & -1.0107 & 0.0118 & -0.0198 & 0.0102 & -0.0203 \\
\hline-0.0017 & 1.3859 & -1.0308 & -0.0273 & 0.8145 & -0.4428 & -4.2307 & 0.0009 & -1.5614 & 2.6181 & 0.0004 & 3.1788 \\
\hline-0.6561 & 0.2894 & 0.9825 & 3.5014 & -0.3801 & -0.6826 & 0.0092 & 0.0012 & 0.0091 & -0.0021 & -1.0473 & 0.0366 \\
\hline-0.5123 & -2.8949 & 0.9669 & 3.6176 & 3.0413 & -1.0986 & 0.0050 & -1.0107 & 0.0118 & -0.0198 & 0.0102 & -0.0203 \\
\hline
\end{tabular}

Table 5 - Weights and biases between the second hidden layer and the output layer

\begin{tabular}{r|r|r|r|r}
\hline \multicolumn{3}{c|}{ Second hidden layer - output layer connections } & \multicolumn{1}{c}{$b_{p\{p=1: 3\}}$} \\
\hline-1.0107 & 0.0118 & -0.0198 & 0.0102 & -0.0203 \\
\hline 0.0009 & -1.5614 & 2.6181 & 0.0004 & 3.1788 \\
\hline 0.0012 & 0.0091 & -0.0021 & -1.0473 & 0.0366 \\
\hline
\end{tabular}

\section{Conclusion}

In this study, the adsorbent capability of thee dyes (AB92, DG6, and DR31) on (GPN) was modelled using the ANN approach. A total of 414 experimental data points were collected from the work of Mahmoodi et al. ${ }^{10}$ The best ANN model was found with $\{9-11-4-3\}$ structure, taking into account the hyperbolic tangent sigmoid and the linear transfer function in the hidden layer and the output layer, respectively. The obtained determination coefficient was larger than 0.999 approaching the ideal fitting status with $R^{2}=1$, and the largest mean squared error was lower than 0.5445 . The obtained statistical parameters confirmed the accuracy of the ANN model to fit the competitive adsorp- tion process of dyes on GPN. The best fitting training data was attained with 4-18-1.

\section{References \\ Literatura}

1. P. R. Jena, J. K. Basu, S. De, A generalized shrinking core model for multicomponent batch adsorption processes, Chem. Eng. J. 102 (2004) 267-275, doi: https://doi.org/10.1016/j. cej.2003.12.006.

2. Y. Nan, L. L. Tavlarides, D. W. DePaoli, Adsorption of iodine on hydrogen-reduced silver-exchanged mordenite: Experiments and modeling, AIChE J. 63 (2017) 1024-1035, doi: https://doi.org/https://doi.org/10.1002/aic.15432.

3. B. Noroozi, G. A. Sorial, Applicable models for multi-component adsorption of dyes: A review, J. Environ. Sci. (China) 25 (2013) 419-429, doi: https://doi.org/10.1016/S10010742(12)60194-6.

4. A. Bašić, M. N. Mužek, L. Kukoč-Modun, S. Svilović, Competitive Heavy Metal Removal from Binary Solution, Kem. Ind. 69 (2020) 465-471, doi: https://doi.org/10.15255/ kui.2020.038.

5. N. Milčić, M. Česnik, M. Sudar, Z. Findrik Blažević, Primjena matematičkog modeliranja u razvoju enzimskih kaskadnih reakcija, Kem. Ind. (9-10) 68 (2019) 427-436, doi: https:// doi.org/10.15255/KUI.2019.035.

Table 6 - Results comparison between this study and previously published papers on modelling dye adsorption by ANN

\begin{tabular}{|c|c|c|c|c|}
\hline Refs. & Dye ${ }^{*}$ & Adsorbent & $\begin{array}{l}\text { Optimal number } \\
\text { of neurons }\end{array}$ & Evaluation indices \\
\hline \multirow{3}{*}{ this study } & AB92+DG6+DR31 & \multirow{3}{*}{$\begin{array}{l}\text { Gemini polymeric } \\
\text { nanoarchitecture }\end{array}$} & $9-11-4-3$ & $R^{2}=0.9999, \mathrm{MSE}=0.2717$ \\
\hline & DG6+DR31+AB92 & & $9-11-4-3$ & $R^{2}=0.9997, \mathrm{MSE}=0.2885$ \\
\hline & AB92+DG6+DR31 & & $9-11-4-3$ & $R^{2}=0.9997, \mathrm{MSE}=0.5445$ \\
\hline Celekli et al. ${ }^{17}$ & Lanaset red G & Walnut husk & $4-20-1$ & $\begin{array}{l}R^{2}=0.995-0.999 \\
M S E=0.4993-5.0057\end{array}$ \\
\hline \multirow{2}{*}{ Hajati et al. ${ }^{18}$} & $\mathrm{AY} 41+\mathrm{SY}$ & \multirow{2}{*}{$\begin{array}{l}\mathrm{SnO}_{2} \text { nanoparticle loaded } \\
\text { activated carbon }\end{array}$} & $5-10-2$ & $R^{2}=0.99, \mathrm{MSE}=0.53$ \\
\hline & $\mathrm{SY}+\mathrm{AY} 41$ & & $5-10-2$ & $R^{2}=0.98, \mathrm{MSE}=0.79$ \\
\hline Malekbala et al. ${ }^{19}$ & AR57 & $\begin{array}{l}\text { Mesoporous carbon-coated } \\
\text { monolith }\end{array}$ & $3-21-1$ & $\begin{array}{l}R^{2}=0.997 \\
M S E=0.9365-6.6529\end{array}$ \\
\hline \multirow{2}{*}{$\begin{array}{l}\text { Parthasarathy and } \\
\text { Narayanan }\end{array}$} & BB41+BR18 & \multirow{2}{*}{$\mathrm{NiO}-\mathrm{MnO}_{2}$ nanocomposite } & $3-4-2$ & $R^{2}=0.9950$ \\
\hline & $\mathrm{BB} 41+\mathrm{BR} 46$ & & $3-6-2$ & $R^{2}=0.9995$ \\
\hline Tanhaei et al. ${ }^{21}$ & Methyl Orange & $\begin{array}{l}\text { Chitosan } / \mathrm{Al}_{2} \mathrm{O}_{3} / \mathrm{Fe}_{3} \mathrm{O}_{4} \text { core-shell } \\
\text { composite microsphere }\end{array}$ & $2-8-1$ & $R^{2}=0.998$, MSE $=101.67$ \\
\hline
\end{tabular}

*BB41: Basic Blue 41, AB92: Acid Blue 92, DG6: Direct Green 6, DR31: Direct Red 31, AR57: Acid Red 57, AY41: Acid Yellow 41, SY: Sunset Yellow, BR18: Basic Red, BR46: Basic Red 46. 
6. C. J. Radke, J. M. Prausnitz, Adsorption of organic solutes from dilute aqueous solution of activated carbon, Ind. Eng. Chem. Fund. 11 (1972) 445-451, doi: https://doi. org/10.1021/i160044a003.

7. M. Moussaoui, M. Laidi, S. Hanini, M. Hentabli, Artificial neural network and support vector regression applied in quantitative structure-property relationship modelling of solubility of solid solutes in supercritical $\mathrm{CO}_{2}$, Kem. Ind. 69 (2020) 611-630, doi: https://doi.org/10.15255/KUI.2020.004.

8. H. Benimam, C. Si-Moussa, M. Laidi, S. Hanini, Modeling the activity coefficient at infinite dilution of water in ionic liquids using artificial neural networks and support vector machines, Neural Comput. Appl. 32 (2020) 8635-8653, doi: https:// doi.org/10.1007/s00521-019-04356-w.

9. H. Benimam, C. S. Moussa, M. Hentabli, S. Hanini, M. Laidi, Dragon $\mathrm{fl}$ y-Support Vector Machine for Regression Modeling of the Activity Coefficient at Infinite Dilution of Solutes in Imidazolium Ionic Liquids Using $\sigma$ - Profile Descriptors, J. Chem. Eng. Data 65 (6) (2020) 3161-3172, doi: https://doi. org/10.1021/acs.jced.0c00168.

10. N. M. Mahmoodi, J. Abdi, F. Najafi, Gemini polymeric nanoarchitecture as a novel adsorbent: Synthesis and dye removal from multicomponent system, J. Colloid Interface Sci. 400 (2013) 88-96, doi: https://doi.org/10.1016/j. jcis.2013.03.014.

11. M. Laidi, S. Hanini, A. Rezrazi, M. R. Yaiche, A. A. El Hadj, F. Chellali, Supervised artificial neural network-based method for conversion of solar radiation data (case study: Algeria), Theor. Appl. Climatol. 128 (2017) 439-451, doi: https://doi. org/10.1007/s00704-015-1720-7.

12. M. Laidi, S. Hanini, Optimal solar COP prediction of a solar-assisted adsorption refrigeration system working with activated carbon/methanol as working pairs using direct and inverse artificial neural network, International Journal of Refrigeration 36 (2013) 247-257, doi:https://doi.org/10.1016/j. ijrefrig.2012.09.016.

13. S. Belmadani, S. Hanini, M. Laidi, C. Si-moussa, M. Hamadache, Artificial neural network models for prediction of density and kinematic viscosity of different systems of biofuels and their blends with diesel fuel. Comparative analysis, Kem. Ind. 69 (7-8) (2020) 355-364, doi: https://doi.
org/10.15255/KUI.2019.053.

14. S. Lertworasirikul, Drying kinetics of semi-finished cassava crackers: A comparative study, LWT - Food Sci. Technol. 41 (2008) 1360-1371, doi: https://doi.org/10.1016/j. Iwt.2007.09.009.

15. M. Wei, X. Yang, P. Watson, F. Yang, H. Liu, Development of QSAR model for predicting the inclusion constants of organic chemicals with $\alpha$-cyclodextrin, Environ. Sci. Pollut. Res. 25 (2018) 17565-17574, doi: https://doi.org/10.1007/ s11356-018-1917-2.

16. S. Keskes, S. Hanini, M. Hentabli, M. Laidi, Artificial intelligence and mathematical modelling of the drying kinetics of pharmaceutical powders, Kem. Ind. 69 (3-4) (2020) 137152, doi: https://doi.org/10.15255/KUI.2019.038.

17. A. Çelekli, S. S. Birecikligil, F. Geyik, H. Bozkurt, Prediction of removal efficiency of Lanaset Red G on walnut husk using artificial neural network model, Bioresour. Technol. 103 (2012) 64-70, doi: https://doi.org/10.1016/j.biortech.2011.09.106.

18. S. Hajati, M. Ghaedi, Z. Mahmoudi, R. Sahraei, $\mathrm{SnO}_{2}$ nanoparticle-loaded activated carbon for simultaneous removal of Acid Yellow 41 and Sunset Yellow; Derivative spectrophotometric, artificial neural network and optimization approach, Spectrochim. Acta Part A Mol. Biomol. Spectrosc. 150 (2015) 1002-1012, doi: https://doi.org/10.1016/j. saa.2015.06.008.

19. M. R. Malekbala, S. Hosseini, S. Masoudi Soltani, R. Malekbala, T. S. Y. Choong, F. Eghbali Babadi, Development, application, and evaluation of artificial neural network in investigating the removal efficiency of Acid Red 57 by synthesized mesoporous carbon-coated monoliths, Desalin. Water Treat. 56 (2015) 2246-2257, doi: https://doi.org/10.1080/194439 94.2014.959062.

20. P. Parthasarathy, S. K. Narayanan, Effect of Hydrothermal Carbonization Reaction Parameters on, Environ. Prog. Sustain. Energy 33 (2014) 676-680, doi: https://doi.org/10.1002/ep.

21. B. Tanhaei, A. Ayati, M. Lahtinen, B. Mahmoodzadeh Vaziri, M. Sillanpää, A magnetic mesoporous chitosan based coreshells biopolymer for anionic dye adsorption: Kinetic and isothermal study and application of ANN, J. Appl. Polym. Sci. 133 (2016) 1-11, doi: https://doi.org/10.1002/app.43466. 


\section{SAŽETAK}

\section{Praktični alat umjetne neuronske mreže za predviđanje kompetitivne adsorpcije bojila na polimernoj nanoarhitekturi gemini \\ Abdelmadjid El Bey, ${ }^{a}$ Maamar Laidi, a, ${ }^{*}$ Amina Yettou, ${ }^{a}$ Salah Hanini, \\ Abdellah Ibrir,a Mohamed Hentabli, and Hasna Ouldkhaoua}

Cilj ove studije bio je modelirati učinkovitost uklanjanja ternarnog adsorpcijskog sustava pomoću višeslojne unaprijedne neuronske mreže s povratnim rasprostiranjem pogreške (FFBP-ANN). Model ANN-a učen je algoritmom Levenberg-Marquardt, a najbolji model bio je s arhitekturom \{9-11-4-3\} neurona za ulazni, prvi i drugi skriveni sloj te izlazni sloj, na temelju dvaju metričkih pokazatelja: srednje kvadratne pogreške $(\mathrm{MSE})=(0,2717-0,5445)$ i koeficijenta određivanja $\left(R^{2}\right)=(0,9997-0,9999)$. Rezultati su potvrdili robusnost i učinkovitost razvijenog ANN modela za modeliranje procesa adsorpcije.

\section{Ključne riječi}

Kompetitivna adsorpcija, umjetne neuronske mreže, modeliranje, bojila

a Laboratory of Biomaterials and Transport Phenomena (LBMPT), University of Médéa, Algeria

${ }^{\mathrm{b}}$ Laboratory Quality Control, Physico-Chemical Department, Antibiotical Saidal of Médéa, Algeria
Izvorni znanstveni rad Prispjelo 14. listopada 2020. Prihvaćeno 8. prosinca 2020. 